\title{
THE BIOSTRATIGRAPHICAL HISTORY OF LAKE OTALAMPI IN SOUTHERN FINLAND, WITH SPECIAL REFERENCE TO THE REMAINS OF SUBFOSSIL MIDGE FAUNA
}

\author{
Pentti Alhonen * and Maija-Liisa Haavisto ** \\ * Department of Geology and Palaeontology, University of Helsinki \\ ** Geological Survey of Finland, Otaniemi, Finland
}

\begin{abstract}
The biostratigraphical history of a small lake Otalampi in southern Finland has been studied. The remains of subfossil Bosmina have been analysed and the biostratigraphy of the larvae of lacustrine Diptera has now been applied in Finnish palaeolimnology. It has been shown in this paper that the phantom midge larva (Chaoborus) with the midge groups Tanytarsarie and Chironomarie predominate in the early history of the lake. After the stratigraphical transition from fine to coarse detritus gyttja Orthocladiinae occur in abundance and are associated with Tanytarsarie and Chironomarie. In pollen zone IX Chironomarie clearly increase and with Tanytarsarie they form the predominating species in the midge community. The occurrence of Chaoborus at the bottom part of the core is believed by authors that the lake initially had a more or less reduced hypolimnion and that the lake was more eutrophic in character. O1thocladiinae, Tanytarsarie and probably Chironomarie in the upper part of the biostratigraphy might indicate that Lake Otalampi was more oligotrophic with a well-oxygenated hypolimnion. Lake Otalampi is now eutrophic.
\end{abstract}

\section{Introduction}

The purpose of this study is to investigate the geological and biological development of a small lake Otalampi in southern Finland. The methods used in this study have mainly been biostratigraphical. The remains of subfossil Bosmina have been analysed and the biostratigraphy of the larvae of lacustrine Diptera, well preserved in lake sediments, has now been applied in Finnish Palaeolimnology.

The larvae of Diptera living in shallow and deep water constitute one of the major elements of the littoral and especially profundal biomass. Moreover, the species present in the deepwater benthos are controlled by the chemical conditions of the hypolimnion, and they are thus very significant organisms in palaeolimnology and their study provides a valuable means of interpreting the past conditions of a lake.

The oldest Diptera findings (see Frey 1964, pp. 70-77), in Eocene and Miocene freshwater sediments, are species of Cbironomus, while Chaoborus is first recorded in the Eemian Interglacial of Denmark (Frey 1962).

\section{Description of the lake}

Otalampi (see Fig. 1), in the parish of Vihti, is a morphometrically longish small lake with 


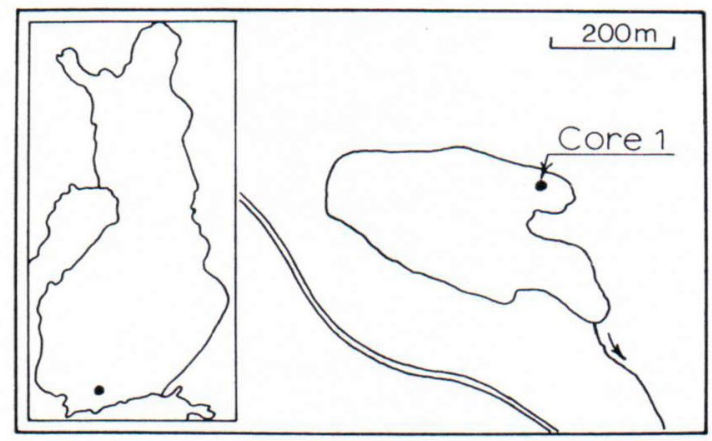

Fig. 1. Location of Lake Otalampi and its sampling site

a north-west - southeasterly direction. Its geographical location is $60^{\circ} 24^{\prime} \mathrm{N}$ Lat. and $24^{\circ} 30^{\prime} \mathrm{E}$ Long and its altitude is $66 \mathrm{~m}$. The lake has a surface area of 32 hectares.

Otalampi receives additional waters mainly from springs in its bottom and it flows into the Gulf of Finland.

Otalampi is surrounded by Precambrian bedrock consisting mainly of granite rocks. The lake lies just in front of the Late Weichselian endmoraine Salpausselkä I. Clay, which is under cultivation occurs in the north-east side of the lake. There are practically no peat lands in the near environment.

The colour of the water against a white disk is yellowish green. Some limnological observations have been presented in Table 1. According to Järnefelt (1956, p. 183) Otalampi is a more or less eutrophic lake.

\section{Methods}

Core from the bottom sediments of Lake Otalampi has been taken with a plexiglass piston sampler (Alhonen 1963, Fig. 1 and 1967, p. 5). The preparation method of the samples for the pollen stratigraphy is essentially the same as that described in the textbook of Faegri \& Iversen (1964).

The quantitative Bosmina analysis has been made from fresh sediment following the method described by Deevey (1942). In microscopy each Bosmina head and shell have been counted as one unit. Two shell halves were counted as one shell (cf. Alhonen 1967, p. 6).

The remains of Diptera were analysed using the method described by Megard (1962). The organic matter of the sediment has been shown as loss-on-ignition at $550^{\circ} \mathrm{C}$. The ignition loss and water content of the sediment are given in the diagram as percentages.

TABle 1. Some limnological observations of Lake Otalampi (Järnefelt 1956)

\begin{tabular}{|c|c|}
\hline Transparency (m) & 2 \\
\hline Colour (Pt $\mathrm{mg} / \mathrm{l})$ & 40 \\
\hline Alkalinity ( $\mathrm{ml} 1 \mathrm{~N}$ & \\
\hline $\mathrm{HCl} / \mathrm{l}) \ldots \ldots$ & 0.23 \\
\hline $\mathrm{Cl}(\mathrm{mg} / \mathrm{l}) \ldots \ldots$ & 3.1 \\
\hline $\mathrm{SO}_{4}(\mathrm{mg} / \mathrm{l}) \ldots \ldots$ & 13.9 \\
\hline $\mathrm{Fe}(\mathrm{mg} / \mathrm{l}) \ldots \ldots$ & 0.22 \\
\hline Vegetation ..... & $\begin{array}{l}\text { Phragmites communis, Equisetum sp., } \\
\text { Nymphaea } \mathrm{sp} .\end{array}$ \\
\hline Plankton ....... & $\begin{array}{l}\text { Eutrophic indicators: Microcystis aeru- } \\
\text { ginosa, } M \text {. flos aquae, } M \text {. pulverea }+ \text { var. } \\
\text { incerta, Coelastrum cambricum, Dictyo- } \\
\text { sphaericum elegans, Kirchueriella elongata, } \\
K \text {. lunaris, Gonium pectorale, Melosira } \\
\text { islandica, Peridinium bipes, Crucigenia } \\
\text { crucifera, Pediastrum boryanum, Scenedes- } \\
\text { mus arcuatus, Cosmarium bioculatum, } \\
\text { Trachelomonas volvocina, and Synedra } \\
\text { acus var. angustissima } \\
\text { Oligotrophic indicators: Arthodesmus } \\
\text { incus, Dinobryon bavaricum, D. divergens } \\
\text { and Stichogloca olivacea }\end{array}$ \\
\hline Fishes $\ldots \ldots \ldots$ & $\begin{array}{l}\text { Esox lucius, Perca fluviatilis, Leuciscus } \\
\text { rutilus, Lota vulgaris and Ancerina } \\
\text { cernua }\end{array}$ \\
\hline
\end{tabular}

\section{The core and pollen stratigraphy}

The sediment core of Lake Otalampi was taken from the east end of the lake. The depth of water at the coring place was about $5 \mathrm{~m}$. The core stratigraphy is of the following kind:

$0-115 \mathrm{~cm}$ coarse detritus gyttja, brown in colour with a greenish tinge

$115-200 \mathrm{~cm}$ greenish grey fine detritus gyttja $200-210 \mathrm{~cm}$ grey clay-gyttja, which according to diatoms is an isolation sediment deposited on Ancylus clay 


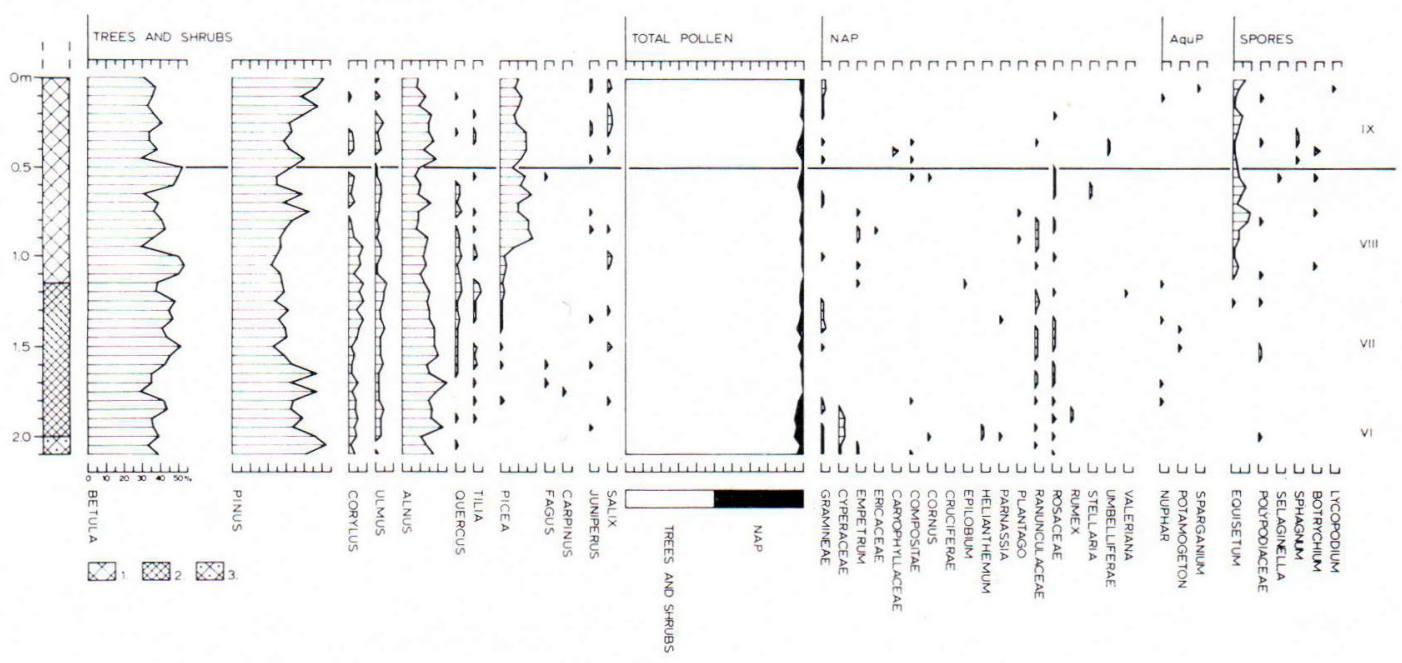

Fig. 2. Pollendiagram of Lake Otalampi. The symbols of stratigraphy: $1=$ coarse detritus gyttja, $2=$ fine detritus gyttja and $3=$ clay-gyttja.

The pollen stratigraphy of Lake Otalampi is presented in the diagram of Fig. 2. This Flandrian (a term according to West 1968, pp. 217-234) pollen profile has been divided into zones according to the scheme of Donner (1963, pp. 4 7) for southern Finland. The upper part of claygyttja, fine detritus gyttja and the lower part of coarse detritus gyttja belong to the Flandrian zones VI, VII and VIII. The zone boundary VIII/IX has been defined on the basis of the curves of thermophilous trees (Quercetum mixtum) and it occurs at a depth of $50 \mathrm{~cm}$ in the coarse detritus gyttja. This zone transition indicates the end of Postglacial Hypsithermal Interval or Flandrian climatic optimum. A $\mathrm{C}^{\mathbf{1 4}}$-date for zone transition VIII/IX, 440 B.C., from the bottom deposits of Lake Sarkkilanjärvi in southwestern Finland (Alhonen 1967, Fig. 8 and 1968, Fig. 2 and Table 1) seems to be in rather good agreement with the other results ( $c f$. Sauramo 1958 and Donner 1963).

In the part diagram of spores the beginning of the curve of Equisetum coincides with the stratigraphical transition from fine to coarse detritus gyttja. Both findings are evidences of the regressive change in the bathymetry of Lake Otalampi.

\section{The biostratigraphy of Bosmina and the water content and organic content of the core.}

Fig. 3 shows the stratigraphical distribution of Bosmina cladoceran. As is evident from the diagram Bosmina has a large Hypsithermal maximum, where there are about 43000 fragments per $1 \mathrm{~cm}^{3}$ of fresh sediment. Thereafter the curve declines very rapidly rising to the second smaller maximum consisting about 20000 Bosmina remains in the pollen zone IX. The stratigraphical position of the Bosmina maximum is in coarse detritus gyttja just above the sediment transition.

The water content and organic content of the sediment core are presented in Fig. 4. There is a low organic content and comparatively little water in clay-gyttja and in the lower part of fine detritus gyttja. The amount of water and that of organic matter increase rapidly and almost 


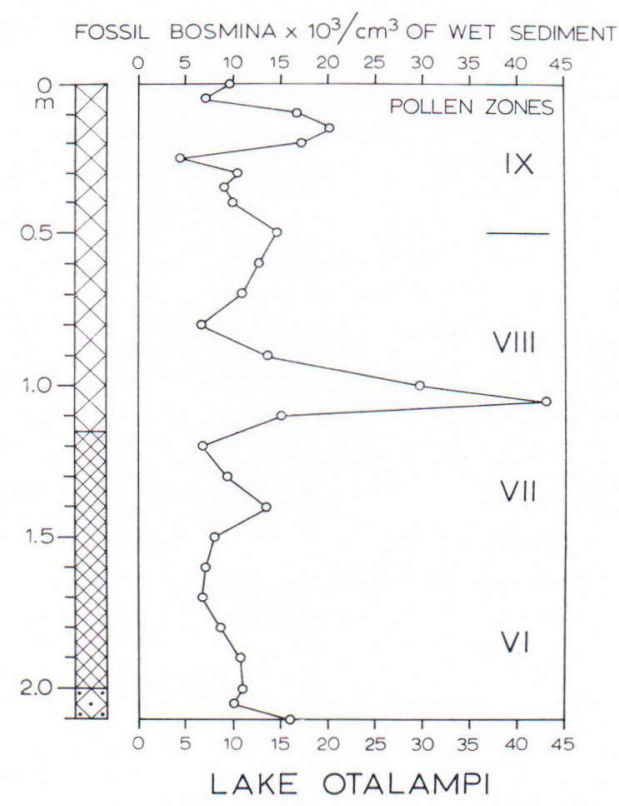

Fig. 3. Lake Otalampi: The stratigraphical distribution of Bosmina.

simultaneously, reflecting the increase in organic production during the Flandrian climatic optimum. Thereafter the curve of the ignition loss declines slightly, while the a mount of minerogenic material (and biogenic silica) increases in the pollen zone IX. The water content tends to rise, although the curves run almost parallel. The development of the organic matter during the history of Lake Otalampi seems to be rather similar to that of other lakes in south-western Finland ( $c f$. Alhonen 1967, Fig. 17). The curves for loss-on-ignition roughly follow the climatic changes obtaining the maximal amounts in the temperate sequence. This is also apparent in the other interglacial stages of the Pleistocene (see e.g. Frey 1962, Fig. 1).

\section{The biostratigraphy of the midge fauna and its interpretation}

Fig. 5 shows the stratigraphical distribution of the midge remains in the Otalampi core. In the

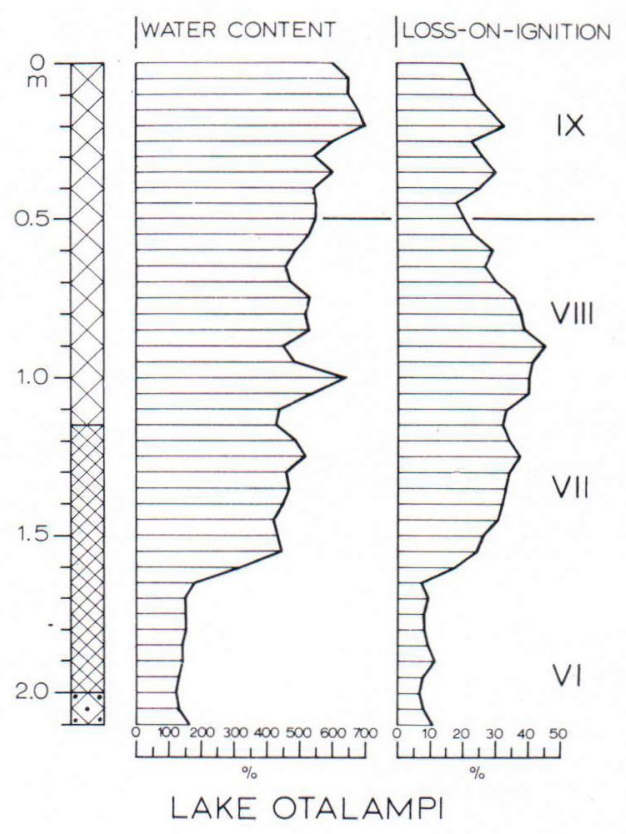

Fig. 4. Lake Otalampi: The water content and loss-onignition of the sediment.

\section{LAKE OTALAMPI,CORE 1}

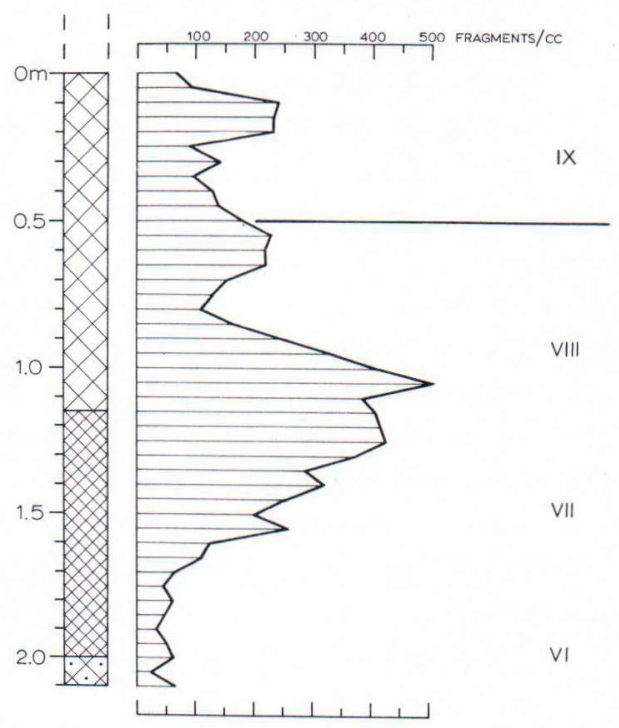

Fig. 5. Lake Otalampi: The stratigraphical distribution of total midge remains. 
LAKE OTALAMPI, CORE 1

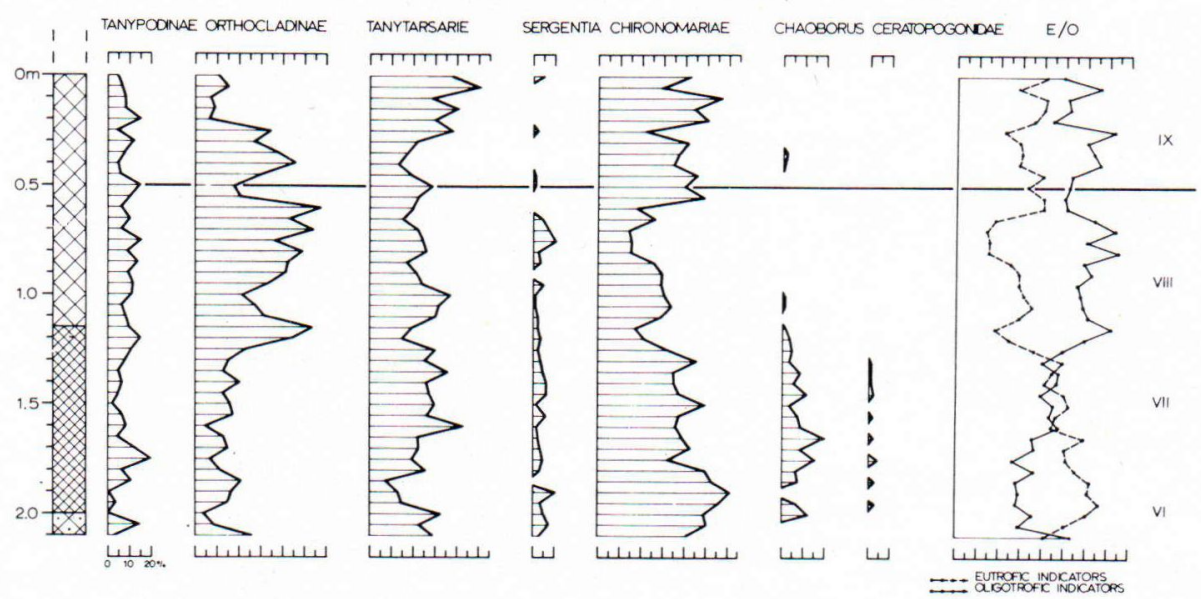

Fig. 6. Lake Otalampi: The biostratigraphy of midge fauna.

diagram it can be seen that the total midge curve rises to its distinct maximum (about 500 fragments per $\mathrm{cm}^{3}$ ) during the Flandrian climatic optimum falling towards the zone transition VIII/IX. Two smaller maxima occur in the upper part of the stratigraphy and the curve has more fluctuation in the pollen zone IX. It can be concluded in this connexion that the midge production also increased with climatic amelioration suggesting probably better limnological conditions in the temperate zones ( $c f$. Frey 1962, p. 1147). Moreover, Jonasson (1964) has shown that the ecological importance of primary production of the phytoplankton for the bottom fauna community lies in the size and seasonal distribution of annual gross production (p. 477).

Fig. 6 presents a more detailed picture of the biostratigraphy of the midge fauna in the Otalampi core. At least three faunal zones can be recognized in the sediments, each characterized by a more or less distinct assemblage of the midge larvae. Some most typical fragments are illustrated on the plates in appendix. As it can be seen in the diagram the phantom midge larva (Chaoborus) with the midge groups Tanytarsarie and Chironomarie predominate in the early history of the lake up to transition from fine det- ritus to coarse detritus gyttja. Thereafter Orthocladiinae occur in abundance and are associated with Tanytarsarie and Chironomarie. In the pollen stratigraphical transition VIII/IX Chironomarie clearly increase, and with Tanytarsarie they form the predominating species in the midge community. Tanypodinae are present throughout the lake's history. The main body of Sergentia occurs in the temperate sequence of the core, and Ceratopogoninae are associated with the first faunal zone characterized by Chaoborus.

Larvae of the various genera of midges are very significant indicators of the past oxygen conditions in the hypolimnion of a lake. Thus they are one of the most important groups of microfossils in the study of Pleistocene lakes. Their biostratigraphy provides a valuable method e.g. for subdividing the Pleistocene.

Thienemann (1913) showed a relationship between profundal midge fauna and oxygen conditions in the hypolimnion. The ecological and limnological interpretation of the mitge remains of Lake Otalampi was based on his suggestion. The occurrerce of Chaoborus at the bottom part of the core suggests that the lake initially had a more or less reduced oxygen content in deep water. Therefore Cbaoborus also in this case was 
associated with a more productive stage of lake development. Other midges, especially Orthocladiinae, Tanytarsarie and probably Chironomarie in the upper part of the biostratigraphy might indicate that Lake Otalampi was rather oligotrophic with a well-oxygenated hypolimnion (Järnefelt 1953). In an opinion presented by Brundin (1949) midges have been overestimated as trophic indicators, but they give a better picture of the temperature and oxygen standard, and according to him there is no binding connexion between the trophic and the oxygen standards of a lake (Brundin, op.c., p. 880).

\section{Some comparisons}

We will now briefly compare our results with some of the best known midge successions of the Pleistocene lakes.

In Linsley Pond Deevey (1942) found Tanytarsus in the early oligotrophic phase of the lake (see also Deevey 1953, p. 284). This bottom fauna was followed first by an intermediate and finally by an eutrophic Tendipes (= Chironomus) fauna. The change in faunal succession of Linsley Pond probably occured at the time of pollen zone C 2, which corresponds approximately with zone VIII in the Middle European zoning system. The phantom midge Chaoborus also appeared in numbers simultaneously. Frey (1955) also found for Längsee that the earlier oligotrophic midge fauna was followed by Chaoborus.

In Estwaite Water in England (see Goulden 1964 a, Fig. 8 and b, Fig. 2) the midge Chironomus appeared in abundance in the upper part of the stratigraphy and began to replace Sergentia and Tanytarsus suggesting that Esthwaite Water was tending towards an eutrophic condition with an anaerobic hypolimnion.

The lakes discussed above are classical examples of the normal sequence from oligotrophy to eutrophy during the lake ontogeny. Our lake is not such a clear case, but we can safely say that it has been more productive in its earlier stages, if the interpretation of its midge typology is correct. We must, however, keep in mind that the disappearence of Chaoborus coincides with the stratigraphical change from fine to coarse detritus gyttja (see Fig. 6). This indicates that Lake Otalampi became shallower and the oxygenation was thus greater in the hypolimnion.

\section{Explanation of Plate $I$}

Some typical midge remains in the Otalampi core:

1. Chaoborus (Corethridae) mandible, $35 \mathrm{~cm}$ depth of sediment. $300 \mathrm{x}$.

2. Procladius (Tanypodinae) head capsule, $10 \mathrm{~cm}$ depth of sediment. $300 \mathrm{x}$.

3. Tanytarsus (Tanytarsarie) head capsule, $25 \mathrm{~cm}$ depth of sediment. $300 \mathrm{x}$.

4. Dryadotanytarsus? (Tanytarsarie) head capsule, $15 \mathrm{~cm}$ depth of sediment. $300 \mathrm{x}$.
5. Microtendipes (Chironomarie) head capsule, $40 \mathrm{~cm}$ depth of sediment. $300 \mathrm{x}$.

6. Orthocladiinae head capsule, $40 \mathrm{~cm}$ depth of sediment. $300 \mathrm{x}$.

7. Parachironomus (Chironomarie) head capsule, $30 \mathrm{~cm}$ depth of sediment. $300 \mathrm{x}$.

8. Polypedilum (Chironomarie) head capsule, $15 \mathrm{~cm}$ depth of sediment. $300 \mathrm{x}$.

9. Orthocladius (Orthocladiinae) head capsule, $140 \mathrm{~cm}$ depth of sediment. $300 \mathrm{x}$. 
PLATE I
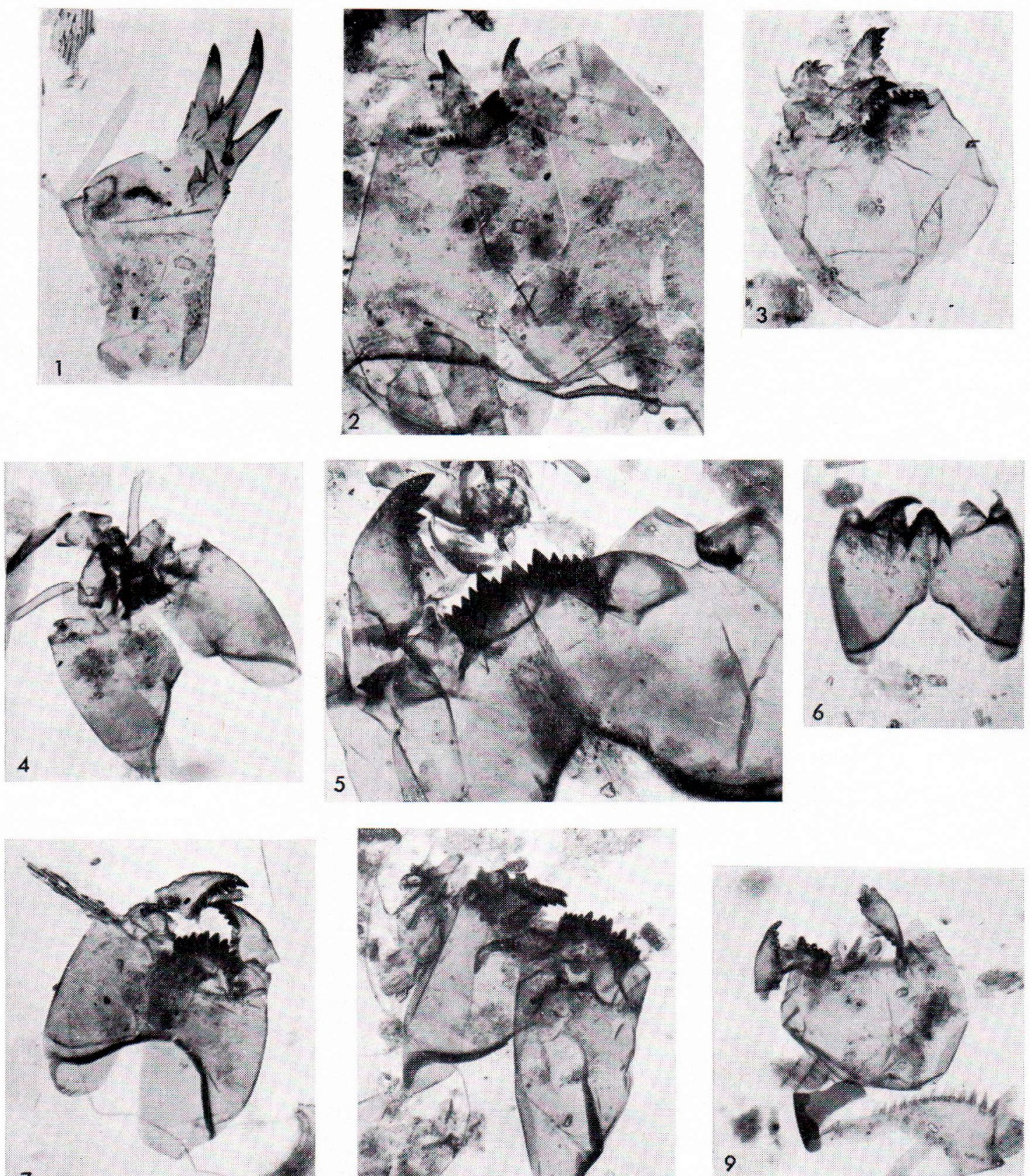

7
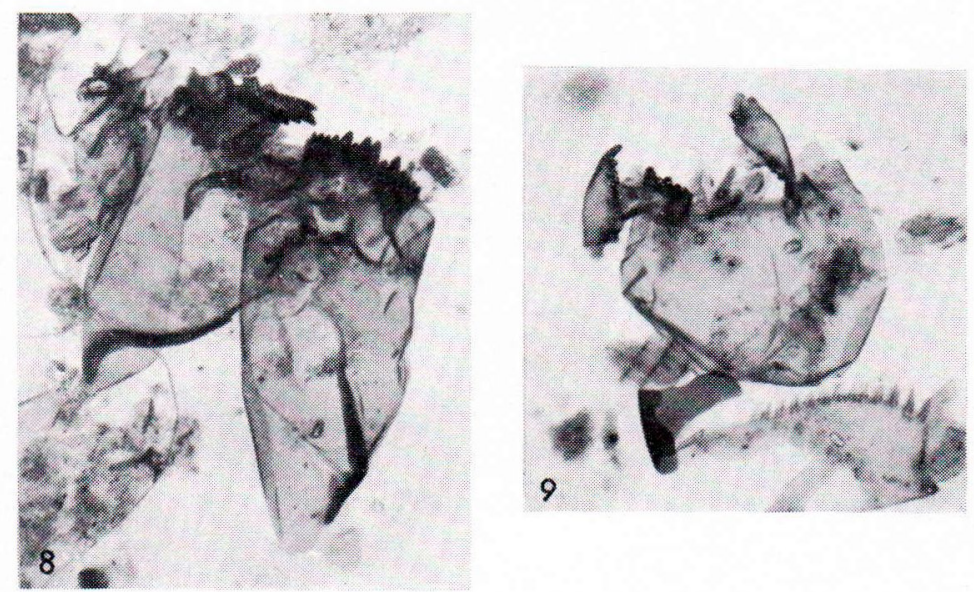


\section{REFERENCES}

Alhonen, Pentri, 1963: Kyrösjärven pohjakerrostumat paleolimnologisena arkistona (English Summary: The bottom sediments of Lake Kyrösjärvi, SW-Finland, as palaeolimnological data. A preliminary report). Suomen Kalastuslehti 7: 191-196.

Alhonen, Pentti, 1967: Palaeolimnological investigations of three inland lakes in south-western Finland. Acta bot. fenn. 76, 59 pp.

Brundin, Lars, 1949: Chironomiden und andere Bodentiere der südschwedischen Urgebirgseen. Rep. Inst. Freshw. Res. Drottningholm 30, 915 pp.

Deever, E. S., 1942: Studies on Connecticut lake sediments. III. The biostratonomy of Linsley Pond. Amer. J. Sci. 240: 233-264.

- 1953: Paleolimnology and climate. In Climatic change ed. H. Shapley. Harward University Press, pp. $273-$ 318.

Donner, J. J., 1963: The zoning of the Post-glacial pollen diagrams in Finland and the main changes in the forest composition. Acta bot. fenn. 65, 40 pp.

Faegri, Knut and Iversen, Johs., 1964: Textbook of pollen analysis. Munksgaard, Copenhagen, 237 pp.

Frey, DAvid, G., 1955: Längsee: a history of meromixis. Mem. Ist. ital. Idrobiol., suppl. 8: 141-164.

- 1962: Cladocera from the Eemian Interglacial of Denmark. Journal of Paleontology 36: 1133-1154.

- 1964: Remains of animals in Quaternary lake and bog sediments and their interpretation. Arch. Hydrobiol. Beih. Ergebn. Limnol. 2, 114 pp.
Goulden, Clyde, E., 1964 a: The history of the Cladoceran Fauna of Esthwaite Water (England) and its limnological significance. Arch. Hydrobiol. 60: 1-52.

- 1964 b: Progressive changes in the cladoceran and midge fauna during the ontogeny of Esthwaite Water. Verh. Internat. Verein. Limnol. 15: 1000-1005.

Jonasson, Petur, M., 1964: The relationship between primary production and production of profundal bottom invertebrates in a Danish eutrophic lake. Verh. Internat. Verein. Limnol. 15: 471-479.

JÄRNEFELT, H., 1953: Die Seetypen in bodenfaunistischer Hinsicht. Ann. Soc. »Vanamo» 15: 37 pp.

- 1956: Zur Limnologie einiger Gewässer Finnlands. XVI. Ann. Zool. Soc. "Vanamo» 17, 201 pp.

Megard, Robert, O., 1964: Biostratigraphic history of Dead Man Lake, Chuska mountains, New Mexico. Ecology 45: 529-546.

Sauramo, Matti, 1958: Die Geschichte der Ostsee. Ann. Acad. Sci. Fennicae A III 51, 522 pp.

Thienemann, A., 1913: Der Zusammenhang zwischen dem Sauerstoffgehalt des Tiefenwassers und der $\mathrm{Zu}$ sammensetzung der Tiefenfauna unserer Seen. Rev. ges. Hydrobiol. u. Hydrogr., 6: 243-249.

West, R. G., 1968: Pleistocene Geology and Biology. Longmans, Green \& Co Ltd, London, 377 pp.

Manuscript received, January 16, 1969. 